\title{
Okullarımız Yapılandırmacı Öğrenme Ortamlarına Ne Kadar Sahip? Ortaokul Öğrencilerinin Algıları Üzerine Boylamsal Bir Bakış*
}

\author{
İbrahim ERDOĞAN1, Murat POLAT² \\ ${ }^{1}$ Prof. Dr., Mus Alparslan Üniversitesi, Eğitim Fakültesi, Matematik. ve Fen Bilimleri Eğitimi Bölümü, i.erdogan@alparslan.edu.tr \\ ${ }^{2}$ Yrd.Doç.Dr., Mus Alparslan Üniversitesi, Eğitim Fakültesi, Eğitim Bilimleri Bölümü, m.polat@alparslan.edu.tr
}

$\mathrm{Bu}$ araştırmanın temel amacı ortaokul öğrencilerinin algılarına göre okullarımızın yapılandırmacı öğrenme ortamlarına ne kadar sahip olduklarının boylamsal bir analizini yapmaktır. Araștırma, boylamsal "Panel Tarama" türünde yürütülmüştür. Araştırmanın örneklem grubunu 2011-2014 yılları arasında Muş ili merkezine bağı farklı ortaokullarda öğrenim gören $n=2526$ (kız=1263; erkek=1263) ortaokul öğrencileri olușturmaktadır. Veri toplama aracı olarak; kișisel bilgi formu ve Taylor ve Fraser (1991) tarafindan geliştirilip Johnson ve McClure (2004) tarafindan tekrar gözden geçirilen "Constructivist Learning Environment Survey (CLES)" Türkçe formundan olușan ölçme envanter formu, öğrencilerin öğrenme ortamı hakkında sahip oldukları algıları tespit etmek amacıyla kullanılmıştır. Araştırmada kullanılan ölçeği Yılmaz-Tüzün, Çakıroğlu ve Boone (2006) Türkçe'ye uyarlamışlardır. Dağııılan ölçme envanter formunun geriye dönüş oranı ortalaması \% $\% 0.2$ 'dir. Ulaşılan çalışma verileri üzerinde Leven's test, t-testi, tek yönlü varyans analizi (ANOVA) ve Post-hoc testleri (Dunnett C, Tukey ve Scheffe) yapılmıştır. Araştırma sonunda; öğrencilerin okullarındaki yapılandırmacı öğrenme ortamına ilișkin algılarının cinsiyet, sınıf düzeyi ve öğrenim gördükleri yıl değişkenleri açısından anlamlı şekilde farklılaştığı ortaya çıkmıştır. Kız öğrenciler erkek öğrencilere oranla daha fazla oranda okullarında yapilandırmacı bir öğrenme ortamı olduğu algisına sahiptirler. Ayrıca 5. ve 6. sınıf öğrencileri, 7. ve 8. sınıf öğrencilerine göre daha yüksek düzeyde okullarında yapılandırmacı bir öğrenme ortamı olduğunu belirtmișlerdir. Öğrencilerin algılarının öğrenim gördükleri yıl açısından ise, 2011 yllından sonraki yıllara oranla daha yapılandırmacı bir öğrenme ortamı olduğu yönünde öngörülenin aksine bir sonuca işaret ettiği ortaya çıkmıştır.

Anahtar Kelimeler: Yapılandırmacılık, yapılandırmacı öğrenme ortamı, ortaokul öğrencileri, yapılandırmacılık algısı, boylamsal araştırma.

\section{How Much Do Our Schools Have Constructivist Learning Environments? A Longitudinal View on Middle School Students' Perceptions}

\begin{abstract}
The main purpose of this research is to make a longitudinal analysis of how much our schools have in the constructivist learning environments according to the perceptions of secondary school students. The research was carried out in the form of a longitudinal "Panel Survey". The sample group of the study consisted of $\mathrm{n}=2526$ (girl=1263, boy=1263) secondary school students studying in different middle schools connected to Muş province center between 2011 and 2014. As a data collection tool; a data collection inventory form consisting of one personal information form and a 20-item Constructivist Learning Environment Survey (CLES) adapted into Turkish by Y1lmazTüzün, Çakıroğlu and Boone (2006) were used. The data collection inventory form has a return rate of $90.2 \%$. Leven's test, t-test, one way variance analysis (ANOVA) and Post-hoc tests (Dunnett C, Tukey and Scheffe) were performed on the study data. At the end of the research; girl students have a higher perception than boy students about to have a constructivist learning environment of the their school, in addition, 5th and 6th grade students stated that they had a constructive learning environment in their schools at a higher level than the 7th and 8th grade students. In terms of the year in which students learn, it turns out that the perceptions point to a contrary to what is predicted in 2011 as a more constructive learning environment than in the following years.
\end{abstract}

Keywords: Constructivism, constructivist learning environment, middle school students, constructivism perception, longitudinal research

\section{GİRİ̧̧}

Geçmişten günümüze eğitim ve öğretim alanında birçok öğrenme kuramı ve felsefesinin dönüşüm ve yenilik adına öne sürüldüğü, geliştirildiği ve halen geliştirilmekte olanlarının bulunduğu bilinen bir gerçektir.

\footnotetext{
* Bu çalışma 30 Mayıs-02 Haziran 2016 tarihlerinde Eskişehir Anadolu Üniversitesinde düzenlenen Dünya Eğitim Bilimleri Derneği'nin (AMSE-AMCE-WAER) XVIII. Dünya Kongresin'de sunulan bildirinin genişletilmiş halidir.
} 
Ancak bu kuramlar içerisinde bugün için belki de en popüler olanlarından biri yapılandırmacı kuram olarak adlandırılmaktadır. Ülkemizde de 2003-2004 eğitim ve öğretim döneminden itibaren yenilenmiş olan okul programlarının bu kuramı temel alarak güncellendiği konunun muhataplarınca birçok kez ifade edilmiştir.

Oysaki yapılandırmacılı̆̆ın bir kuram olarak, 1980’li yıllardan itibaren tüm Dünya'da eğitimcilerin ilgi odağı haline geldiği (Özden, 2003) anlaşılmaktadır. Hatta yapılandırmacı kuramın felsefi alt yapısını oluşturan düşüncelerin 1920’li ylllarda ilerlemeci eğitim felsefesi temelinde John Dewey’nin “okul, yaşamın ta kendisi olmalıdır” düşüncesine dayandırılması da mümkündür. Dewey'nin bireyi merkeze alarak öne sürdügü bu ve benzeri görüşlerinin, özellikle öğrenme ortamlarında öğrenenler için bilginin nasıl daha kalıcı olarak yapılandırılabileceği yönündeki görüşlerinin günümüz yapılandırmacı kuramına dayalı eğitim politikalarında karşıllı̆ını bulduğunu söyleyebiliriz. Nitekim yapılandırmacılık kuramına göre; bilgi, bulunmaz, aktarılmaz, ancak kurulur. Bu bağlamda bilgi, bireyin ürünüdür. Bilgi bu şekilde tanımlandığında ise bilginin kurulmasında gücün öğrenen kaynaklı olduğu (Baki \& Bell 1997; Jonassen, Peck \& Wilson, 1999) gibi bir sonuca ulaşırız. Yapılandırmacı yaklaşım açısından öğrenme ise; bir tür zihnin yeniden örgütlenmesi veya yaşantı ürünü zihinsel yapı değişimidir. Yani bu yaklaşımda "yapılandırmacılık” terimi de zaten bilginin öğrenci tarafindan yapılandırılmasını anlatır. Çünkü bireyler bilgiyi aynen almaz, kendilerinde var olan bilgiyle beraber yeni bilgiyi özümseyip, yine kendi öznel durumlarına uyarlayarak öğrenirler (Özden, 2003).

$\mathrm{Bu}$ bağlamda anlaşılabileceği gibi yapılandırmacı yaklaşımın uygulandığı derslerdeki öğrenme ortamları ile geleneksel modele dayalı işlenen derslerin öğrenme ortamlarının birbirinden oldukça farklı (Meral \& Şimşek, 2014; Ocak ve Tavlı, 2010) olması gerekir. Bu farklı ortamı derslerde oluşturacak kişi ise öğretmendir. Buna göre, özellikle son 30 yılda öğretmenin değişen yeni rolleri arasında en başta gelen rolün "ortam tasarımcısı" olma rolü olduğu pek tabi söylenebilir. Ancak bunun için öğretmenlerin yapılandırmacılık yaklaşımının temel ilkelerinden haberdar olmaları gerekmektedir. Burada öğretmenlerin yapılandırmacıllğı bir öğretme kuramı olarak değil, öğrenme kuramı olarak ele almaları da ayrıca önem arz eder. Bu öğrenme kuramının temel ilkeleri ise (Fosnot 1996; Jonassen, Peck \& Wilson 1999'dan Akt: Arkün ve Aşkar, 2010): Bilginin olduğu gibi aktarılamayacağı, yapılandırılması gerektiği; öğrenmenin gelişmenin bir sonucu değil, gelişmenin ta kendisi olduğu; öğrenenlerin gerçekte organize eden olması, yani kendi öğrenme ortamlarını geliştirmede aktif bir rol almaları; öğrenme sürecinde hataların olması gerektiği, ancak bu hataların küçümsenmemesi ve onlardan kaçınılmaması; öğrencilerin öğrenmelerini sağlayacak açık uçlu ve anlamlı içeriklerin sunulması; yansıtmanın öğrenmeyi hızlandıracağının bilinmesi; öğrencilerin deneyimlerini bir araya getirip yazdıklarında/tartıştıklarında ve öğrendiklerini toparladıklarında öğrenmenin kolaylaşacağı; bu bağlamda öğrenmenin, ancak yapıların gelişimiyle ilerleyen, öğrenenlerin anlamlandırma çalışmalarıyla oluşan, deneyimlerin tekrar genellemesi ve sonuçta önceki yapıların yeniden organize edilmesiyle gerçekleşen bir süreç olduğu haliyle alanyazında yer almaktadır. Diğer yandan öğretmenlerin bir öğrenme ortamı tasarımcısı olarak burada bahsi geçen yapılandırmacıllğın temel ilkelerini bilmeleri yapılandırmacı bir öğrenme ortamı oluşturabilmeleri konusunda tek başına yeterli değildir. Bu türden ortamların nasıl hazırlanması gerektiğine dair ayrıca yol haritalarının da bulunması gerekir.

$\mathrm{Bu}$ anlamda yürütülen araştırmalar içerisinde Cunningham, Duffy, ve Knuth (1993) ile Knuth ve Cunningham'ın (1993) yürütmüş oldukları çalışmalarının öne çıktığı ifade edilebilir. Bu çalışmalara göre, yapılandırmacı öğrenme ortamı hazırlamanın genel ilkeleri (Arkün \& Aşkar, 2010; Honebein, 1998; Küçüközer, Kırtak Ad, Ayverdi \& Eğdir, 2012): Bilgiyi yapılandırma sürecinde öğreneni aktif hale getirmek; sınıf ortamında farklı bakış açılarını gündeme getirerek değerlendirme konusunda deneyim sağlamak; gerçek ve ilişkili içerikler yoluyla öğrenenin bağlam kurması ve öğrenmesini sağlamak; öğreninin öğrenmesinden sorumluluk almasını sağlamak; sosyal etkinlikler ve deneyim kazandırma yoluyla öğrenmeyi sağlamak; öğrenciyi kendini farklı yollarla ifade etme konusunda motive etmek; öğrenenin bilgiyi yapılandırması sürecindeki bireysel farkındalığını arttırmak, şeklinde belirlenmiş olan ilkelerdir. Öğretmenler yapılandırmacıllğın ve yapılandırmacı öğrenme ortamlarının nasıl oluşturulacağının bu çalışmada kendilerine sunulan temel ve genel ilkelerini gözetmeleri durumunda Şekil 1'de verildiği üzere yapılandırmacı öğrenme ortamında öne çıkması 
muhtemel ve birbiriyle ilişkilendirilen toplamda beş farklı alt boyutu da gözetmeleri gerektiğini kavramış olacaklardir..

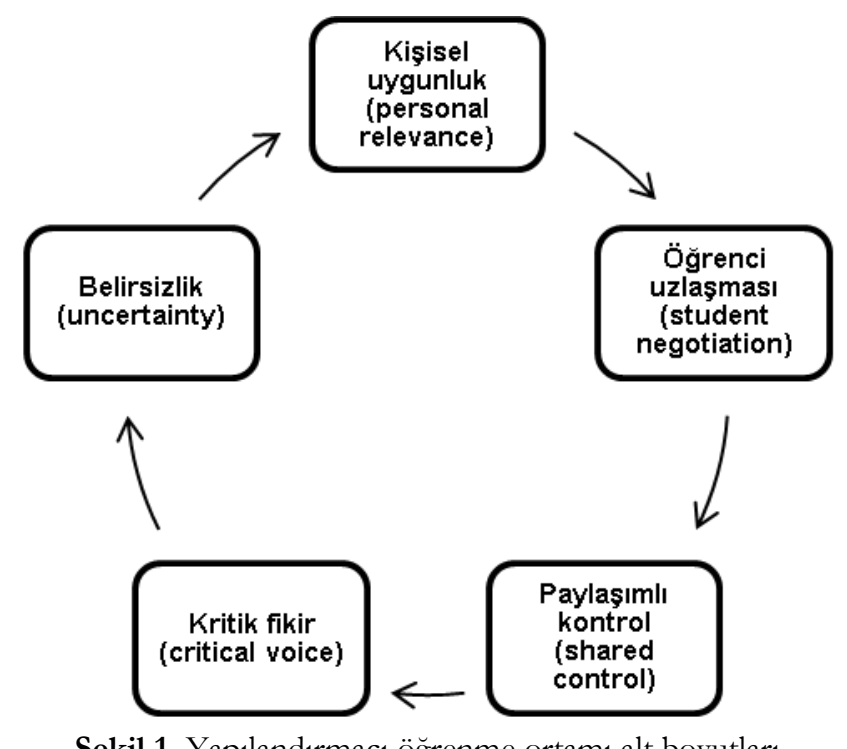

Şekil 1. Yapılandırmacı öğrenme ortamı alt boyutları

Şekil 1'de görülebileceği gibi yapılandırmacı olduğu düşünülen bir öğrenme ortamında "Kişisel uygunluk, Öğrenci uzlaşması, Paylaşımlı kontrol, Kritik fikir ve Belirsizlik” olmak üzere (Arısoy, 2007) birbiriyle ilişkili ancak her biri kendi içinde farklı özellikler barındıran beş alt boyutun olduğu anlaşılmaktadır. Bu alt boyutların bir sınıftaki öğrenme ortamının gelişim süreci açısından bir tür doğal öğrenme döngüsüne benzetilebileceği de ifade edilebilir. Burada kişisel uygunluk, öğrencilerin öğrendikleri bilgilerin okul içinde ve dışındaki deneyimler ile olan ilişkisine; öğrenci uə̧laşması, öğrencilerin daha iyi öğrenmeleri için birbirleriyle etkileşimleri hakkında ne düşündüklerine; paylaşıml kontrol, öğrencilerin kendi öğrenmeleri üzerinde ne derece kontrol sahibi olduğu ile ilgili alg1larına; kritik fikir, Öğrencilerin kendi öğrenmeleriyle ilgili düşüncelerini açıklama özgürlüğüne ne derece sahip olduklarına ve belirsiz̨lik ise Öğrencilerin bilimin belirsiz doğasıyla ilgili algılarına atıfta bulunmaktadır (Arısoy 2007; Belge Can, 2012; Ocak \& Tavlı, 2010; Özkal, Tekkaya \& Çakıroğlu, 2009; Uysal, 2010). Dolayısıyla öğretmenlerin yapılandırmacıllı̆ı̆n bu beş alt boyutunu gözeterek sınıf ortamını yapılandırmaya çaba göstermelerinin öğrenenler/öğrenciler arasında anlamlı öğrenmenin de yolunu açabilecekleri ön görülebilir.

$\mathrm{Bu}$ öngörü konuya ilişkin yürütülen birçok araştırma sonuçlarıyla da sabittir. Başka bir deyişle yapılandırmacı öğrenme yaklaşımını benimseyen sınıflarda, öğrencilerin genellikle anlamlı öğrenme yaklaşımını kullanarak öğrenilecek bilgi ve var olan bilgi arasında ilişkilendirme yaptığı, böylece akranlarıyla uzlaşarak bilgileri yapılandırdıkları ve akademik olarak daha başarılı oldukları tespit edilmiştir (Entwistle \& Tait, 1990; Trigwell \& Prosser, 1991). Ancak Entwistle (1991) konuya meraklı araştırmacı ve öğretmenleri yine de, öğrencilerin kullandıkları öğrenme yaklaşımlarına sınıfın kendisinin değil öğrencilerin sınıfları ile ilgili algılarının etki ettiği ayrımına dikkat edilmesi konusunda uyarmıştır. Bununla birlikte, güncel meta-analiz araştırmaları sonucunda yapılandırmacı yaklaşımının geleneksel öğretim yöntemlerine göre öğrencilerin akademik başarılarında güçlü ve tutumlarında orta düzeyde pozitif etkisi olduğuna (Ayaz \& Şekerci, 2015) işaret etmektedir.

Öte yandan Türkiye özelinde özelikle öğrenme ortamlarının eğitime kazandırdığı sonuçlar önemsenmekle birlikte bu konuda yürütülmüş olan çalısmaların hedef kitlelerinin çoğunlukla ortaöğretim ve yükseköğretim kademelerine devam eden öğrenciler olduğu, bir kaç çalışmanın dışında ilk ve ortaokul kademesinin ihmal edildiği anlaşılmaktadır (Belge Can, 2012). Ayrıca yine Türkiye özelinde konuya ilişkin yürütülmüş boylamsal çalışmalara ise rastlanamamıştır. Bu çerçevede okullardaki yapılandırmacı öğrenme ortamına yönelik olarak ortaokul öğrencilerinin görüşlerini belirlemek amacıyla gerçekleştirilmiş olan bu boylamsal araştırmadan elde edilen sonuçların genelde konuya ilişkin diğer çalışmalara ve özelde ise fen ögretimi alanına önemli katkılar sağlayacağı ön görülmüştür. Çünkü gelecek nesillerinin iyi yetişmeleri yönündeki kaygıların okullar aracıllğıyla giderilmesini beklemek her toplum için önemli bir tartsşma konusudur. Bu açıdan okullarda, kaliteli ve iyi öğretimin yapılabilmesi, eksiklerin veya varsa sorunların giderilebilmesinin yolu eğitimsel süreçleri sorgulayıc1 (Polat \& Köse, 2013) boylamsal çalışmalardan geçmektedir. Bu bağlamda öğrenci görüşlerinin tespitinin 
okullarda daha yapılandırmacı ortamların ve daha etkili öğrenme çevrelerinin nasıl oluşturulabileceğine dair yürütülecek her türden eğitimsel politikaya bir temel oluşturacağı ifade edilebilir. Dolayısıyla bu araştırmanın temel amacı: Ortaokul öğrencilerinin (5, 6, 7 ve 8. sınıflar) algılarına göre okullarımızın yapılandırmacı öğrenme ortamlarına ne kadar sahip olduklarının boylamsal bir incelemesini yapmaktır.

Bu amaçla:

$\checkmark$ Öğrencilerin okullarındaki yapılandırmacı öğrenme ortamına yönelik algılarının ölçeğin bütünü ve alt boyutlarına göre farklılaşıp farklılaşmadı̆̆ına,

$\checkmark$ Öğrencilerin yapılandırmacı öğrenme ortamlarına ilişkin algılarının: Cinsiyet, sınıf düzeyi ve öğrenim görülen yıl değişkenleri açısından değişip değişmediğine bakılmıştır.

\section{YÖNTEM}

Boylamsal araştırma deseninde yürütülen bu araştırmanın türü "Panel Tarama"dır. Panel tarama, zaman içinde tekrarlanan ölçümlerin farklı katılımcılara uygulandığı boylamsal bir tarama türüdür (Metin, 2014). Bu araştırma yoluyla da ortaokul öğrencilerinin zamanla tekrarlanan ölçümler neticesinde yapılandırmacı öğrenme ortamlarına yönelik görüşlerinin tespiti amaçlandığından boylamsal araştırma deseninde ve panel tarama türünde mümkün olduğunca farklı katılımcılarla yürütülmesinin daha geniş kapsamlı sonuçlara ulaştırabileceği düşünülmüştür.

\section{1. Örneklem Grubu}

$\mathrm{Bu}$ araştırmanın örneklem grubunu 2011-2014 yılları arasında Muş ili merkez ilçesine bağlı farklı ortaokullarda öğrenim görmüş veya halen görmekte olan 1263’ü kız; 1263’ü erkek olmak üzere toplam 2526 ortaokul öğrencisi oluşturmaktadır. Buna göre araştırmanın her yllı için tesadüfi olarak belirlenen örneklem grubunu oluşturan öğrencilere ilişkin detaylı bilgiler Tablo 1'de mevcuttur.

Tablo 1. Örneklem grubunun özellikleri

\begin{tabular}{|c|c|c|c|c|c|}
\hline \multirow[b]{2}{*}{ Sınıf Düzeyleri } & \multicolumn{4}{|c|}{ Y1l } & \multirow{2}{*}{$\frac{\text { Toplam }}{\mathrm{n}}$} \\
\hline & 2011 & 2012 & 2013 & 2014 & \\
\hline 5.Sinif & 147 & 87 & 172 & 172 & 578 \\
\hline 6. Sinif & 175 & 155 & 134 & 152 & 616 \\
\hline 7. Sinif & 140 & 152 & 239 & 214 & 745 \\
\hline 8. Sinif & 118 & 133 & 142 & 194 & 587 \\
\hline Toplam & 580 & 527 & 687 & 732 & 2526 \\
\hline Cinsiyet & 2011 & 2012 & 2013 & 2014 & n \\
\hline Erkek & 286 & 259 & 338 & 380 & 1263 \\
\hline $\mathrm{K}_{12}$ & 294 & 268 & 349 & 352 & 1263 \\
\hline Toplam & 580 & 527 & 687 & 732 & 2526 \\
\hline
\end{tabular}

\subsection{Veri Toplama Arac1}

Araştırmada veri toplama aracı olarak; kişisel bilgi formu ve Taylor ve Fraser (1991) tarafindan geliştirilip Johnson ve McClure (2004) tarafindan tekrar gözden geçirilen "Constructivist Learning Environment Survey (CLES)" Türkçe formundan oluşan ölçme envanter formu, öğrencilerin öğrenme ortamı hakkında sahip oldukları algıları tespit etmek amacıyla kullanılmıştır. Araştırmada kullanılan ölçeği Yılmaz-Tüzün, Çakıroğlu ve Boone (2006) Türkçe’ye uyarlamışlardır. Buna göre, "Yapılandırmacı Öğrenme Ortamları Ölçeği (YÖOÖ)" 5’li-Likert (1-1,80=Hiçbir Zaman; 1,81-2,60=Nadiren; 2,61-3,40=Bazen; 3,41-4,20=S1k Sık; 4,21$5,00=$ Çoğunlukla) tipi bir ölçek olup, birbiriyle ilişkili beş farklı alt boyut altında toplanan 20 maddeden oluşmaktadır. Yılmaz-Tüzün, Çakıroğlu ve Boone (2006) analiz birimi olarak grup ortalamasını aldıklarında alt boyutlarının Cronbach Alfa değerlerini belirsiz̨lik boyutu için .59; kritik fikir boyutu için .69; ögrenci uz̆laşması boyutu için .69; kişisel uygunluk boyutu için .72 ve paylaşımlı kontrol boyutu için ise .74 olarak hesaplamışlardır (Akt: Özkal, Tekkaya ve Çakıroğlu, 2009; Uysal, 2010).

$\mathrm{Bu}$ araştırma için YÖOÖ ölçeğine dair hesaplanan KMO değeri .91 ( $\mathrm{p}<.001)$ ve Cronbach's $\alpha$ değeri ise .82’dir (\%95 güven düzeyi için). Ölçeğin alt boyutlarına ilişkin Cronbach’s $\alpha$ değerleri ise: .50 ile .67 arasında değişmektedir. Ölçeğin bu araştırma için beş faktörlü olarak açıkladığı toplam varyans oranı \%48.9'dur. Ölçeğin alt boyutlarına ilişkin birer madde örneği ve madde içeriklerine ilişkin bilgiler Tablo 2'de sunulmuştur. 
Tablo 2. Yapılandırmacı öğrenme ortamı ölçeğinde yer alan madde örnekleri

\begin{tabular}{lcl}
\hline Boyutlar & Madde No & \multicolumn{1}{c}{ Madde İçeriği } \\
\hline Kişisel Uygunluk & 1 & Derslerimizde okul içindeki ve dışındaki dünya hakkında bilgi ediniyorum. \\
Öğrenci Uzlaşması & 5 & $\begin{array}{l}\text { Derslerimizde problemleri nasıl çözeceğimi diğer öğrenciler ile tartışıorum. } \\
\text { Paylaşımlı Kontrol }\end{array}$ \\
Kritik Fikir & 80 & $\begin{array}{l}\text { Derslerimizde herhangi bir etkinlik/aktivite için ne kadar zamana ihtiyacım } \\
\text { olduğunu öğretmene bildiriyorum. }\end{array}$ \\
Belirsizlik & 19 & $\begin{array}{l}\text { Derslerimizde neyin, nasıl öğretildiğini rahatlıkla sorgulamama izin verildiğinde } \\
\text { daha iyi öğreniyorum. } \\
\text { Derslerimizde bilimin, soruların ortaya konması ve çözüm yollarının } \\
\text { oluşturulmasında bir yol olduğunu öğreniyorum. }\end{array}$ \\
\hline
\end{tabular}

\subsection{Veri Analizi}

Öğrencilere dağıtılan ölçme envanter formunun geriye dönüş oranı; analiz için uygun görülmeyenler dışında (eksik kodlama, hep aynı yanıtı verme, vb.) \%90.2'dir. Ulaşılan çalışma verileri üzerinde Leven’s test, ttesti, tek yönlü varyans analizi (ANOVA) ve Post-Hoc testleri (Dunnett C, Tukey ve Scheffe) yapılmıştır.

\section{BULGULAR}

\section{1. Öğrencilerin Yapılandırmacı Öğrenme Ortamı Alg1 Düzeylerine İlişkin Bulgular}

Öğrencilerin yapılandırmacı öğrenme ortamına dair alg1 düzeylerine ilişkin almış oldukları dört yıllık süreç sonundaki toplam puan ortalamalarına ait bulgular Şekil 2'de verilmiştir.

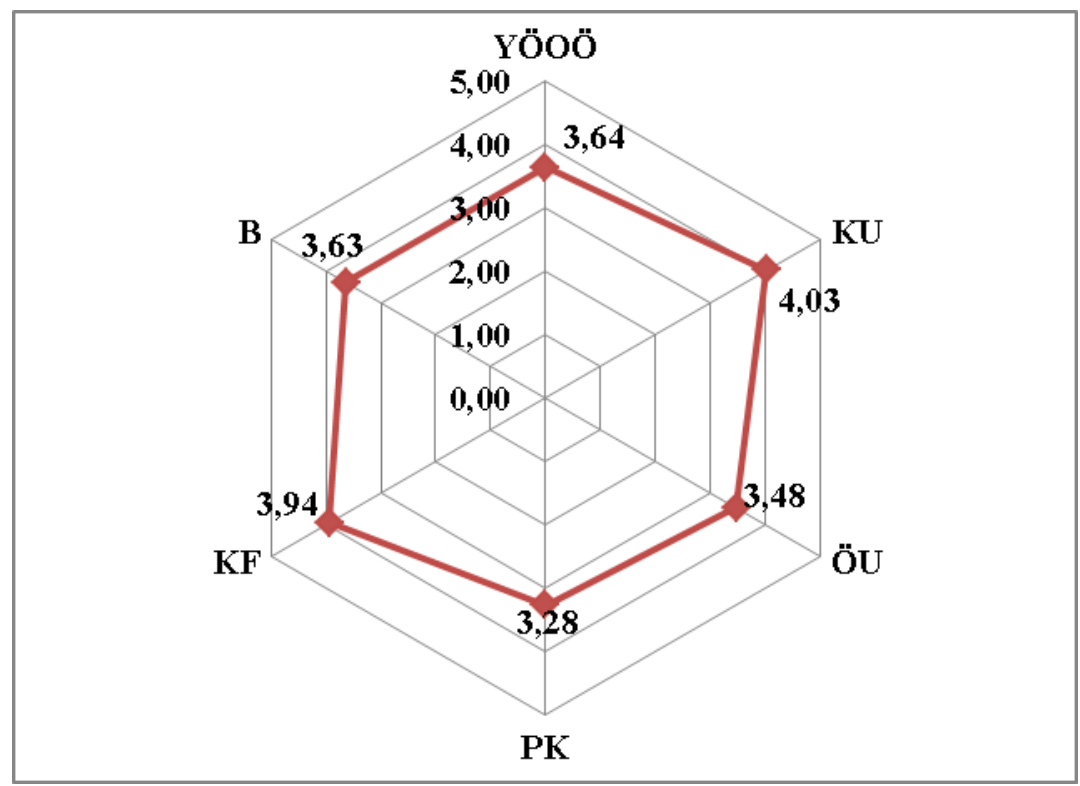

Şekil 2. Öğrencilerin Yapılandırmacı Öğrenme Ortamı Alg1 Düzeyleri

(KU: Kişisel Uygunluk; ÖU: Öğrenci Uzlaşması; PK: Paylaşımlı Kontrol; KF: Kritik Fikir; B: Belirsizlik)

Şekil 2 incelendiğinde öğrencilerin ölçekten aldıkları dört yıllık süreç sonundaki toplam puan ortalamalarının en yüksek düzeyde $\mathrm{M}=4.03$ (Sık sık) ölçeğin kişisel uygunluk boyutunda en düşük düzeyde ise $\mathrm{M}=3.28$ (Bazen) paylaşımlı kontrol boyutunda temsil edildiği görülmektedir. Yani, ortaokul öğrencileri en yüksek düzeyde, öğrendikleri bilgilerin okul içinde ve dışındaki deneyimleri ile olan ilişkisini kurabilme bağlamında yapılandırıcı öğrenme ortamına sahip oldukları görüşündedirler. Kendi öğrenmeleri üzerinde ne derece kontrol sahibi oldukları ile ilgili algılarının ise en düşük oranda olduğu ifade edilebilir.

\section{2. Öğrencilerin yapılandırmacı öğrenme ortamına ilişkin algıları cinsiyetleri açısından} farklılaşmakta mıdır?

Öğrencilerin okullarındaki yapılandırmacı öğrenme ortamına ilişkin algılarının cinsiyetleri açısından incelemek için bağımsız örneklem t-testi yürütülmüştür. Analiz sonucunda öğrencilerin cinsiyetlerine göre algılarının ölçeğin bütününde ve kişisel uygunluk, öğrenci uzlaşması, kritik fikir ve belirsizlik boyutlarında anlamlı şekilde farklılaştı̆̆ı ancak ölçeğin paylaşımlı kontrol alt boyutunda ise herhangi bir farklılaşmaya rastlanmadığı ortaya çıkmıştır. Yani, ölçeğin bütünü için kızların yapılandırmacı öğrenme ortamına ilişkin puanları ortalaması $(\mathrm{M}=3.68, \mathrm{SD}=.55)$ erkeklerinkinden $(\mathrm{M}=3.58, \mathrm{SD}=.56)$ farklıdır ve bu fark istatistiksel açıdan anlamlıdır ( $\mathrm{t}=-4.44, \mathrm{p}<.05, \mathrm{~d}=.18)$. Kızların yapılandırmacı ögrenme ortamına sahip olduklarına dair 
görüşleri erkeklerinkinden daha yüksektir. Etkinin büyüklüğü düşük seviyededir. Bununla birlikte kız öğrenciler erkek öğrencilere oranla daha yüksek düzeyde; okulda öğrendikleri bilgilerin okul içinde ve dışındaki deneyimleri ile ilişkili olduğuna ( $\mathrm{t}=-4.86, \mathrm{p}<.05, \mathrm{~d}=.19)$; okulda daha iyi öğrenmeleri için birbirleriyle daha çok etkileşimde bulunmaları gerektiğine ( $\mathrm{t}=-4.68, \mathrm{p}<.05, \mathrm{~d}=.19)$ ve kendi öğrenmeleriyle ilgili düşüncelerini açıklama özgürlüğüne sahip oldukları $(\mathrm{t}=-5.52, \mathrm{p}<.05, \mathrm{~d}=.21)$ görüşüne sahiptirler. Ayrıca kız öğrencilerin bilimin belirsiz doğasıyla ilgili algılarının ( $\mathrm{t}=-4.26, \mathrm{p}<.05, \mathrm{~d}=.18)$ da erkek öğrencilere oranla daha yüksek düzeyde olduğu belirlenmiştir. Tüm bu sonuçlar Tablo 3’te toplu halde sunulmuştur.

Tablo 3. Öğrenci algılarının cinsiyetlerine göre farklılaşma durumuna ilişkin bağımsız örneklem t-testi sonucu

\begin{tabular}{|c|c|c|c|c|c|c|c|}
\hline Boyutlar & Cinsiyet & $\mathbf{M}$ & SD & $\mathbf{t}$ & $\mathrm{p}$ & Levene's Test & Cohen's d \\
\hline Ölçek Bütünü & Erkek & 3.58 & .56 & \multirow{2}{*}{-4.44} & \multirow{2}{*}{$\mathrm{p}<.05$} & \multirow{2}{*}{$\mathrm{p}>.05$} & \multirow{2}{*}{.18} \\
\hline -YÖÖ̈- & $\mathrm{K}_{1 z}$ & 3.68 & .55 & & & & \\
\hline \multirow{2}{*}{ Kişisel Uygunluk } & Erkek & 3.96 & .73 & \multirow{2}{*}{-4.86} & \multirow{2}{*}{$\mathrm{p}<.05$} & \multirow{2}{*}{$\mathrm{p}<.05$} & \multirow{2}{*}{.19} \\
\hline & $\mathrm{K}_{1 z}$ & 4.10 & .69 & & & & \\
\hline \multirow{2}{*}{ Öğrenci Uzlaşması } & Erkek & 3.39 & .82 & \multirow{2}{*}{-4.68} & \multirow{2}{*}{$\mathrm{p}<.05$} & \multirow{2}{*}{$\mathrm{p}>.05$} & \multirow{2}{*}{.19} \\
\hline & $K_{1 z}$ & 3.55 & .80 & & & & \\
\hline \multirow{2}{*}{ Kritik Fikir } & Erkek & 3.86 & .73 & \multirow{2}{*}{-5.52} & \multirow{2}{*}{$\mathrm{p}<.05$} & \multirow{2}{*}{$\mathrm{p}>.05$} & \multirow{2}{*}{.21} \\
\hline & $K_{1 z}$ & 4.02 & .73 & & & & \\
\hline \multirow{2}{*}{ Belirsizlik } & Erkek & 3.56 & .64 & \multirow{2}{*}{-4.26} & \multirow{2}{*}{$\mathrm{p}<.05$} & \multirow{2}{*}{$\mathrm{p}>.05$} & \multirow{2}{*}{.18} \\
\hline & $K_{1 z}$ & 3.68 & .64 & & & & \\
\hline
\end{tabular}

3.3. Öğrencilerin yapılandırmacı öğrenme ortamına ilişkin algıları sınıf düzeyleri açısından farklılaşmakta midır?

Ortaokul öğrencilerinin okullarındaki yapılandırmacı öğrenme ortamına dair algılarının sınıf düzeyleri açısından incelemek için tek faktörlü gruplar arası varyans analizi (ANOVA) yürütülmüştür. Öğrenciler sınıf düzeylerine göre dört gruba ayrılmıştır ( $A=5$. Sınıf; $B=6$. Sınıf; $C=7$. Sınıf; $D=8$. Sınıf). Analiz sonucunda öğrenci algılarının ölçeğin bütünü, öğrenci uzlaşması, paylaşımlı kontrol ve kritik fikir alt boyutlarında anlamlı şekilde farklılaştı̆̆ı ancak ölçeğin kişisel uygunluk ve belirsizlik alt boyutlarında manidar bir farkın gözlenmediği belirlenmiştir. Buna göre, öğrencilerin yapılandırmacı öğrenme ortamına dair puan ortalamaları sınıf düzeylerine göre istatistiksel açıdan anlamlı düzeyde farklılık göstermektedir $(F=6.26, p<.05, \eta=.08)$.

Ölçeğin bütünü için Scheffe, ve Tukey HSD testi kullanılan Post-hoc kıyaslamalar, 5.sınıf öğrencilerinden elde edilen ortalama puanın $(\mathrm{M}=3.68, \mathrm{SD}=.54)$, 7.sınıf öğrencileri için elde edilen ortalama puandan ( $\mathrm{M}=3.58, \quad \mathrm{SD}=.57)$ anlamlı bir biçimde farklı olduğunu işaret etmektedir. Ayrıca 6.sınıf ögrrencilerinden elde edilen ortalama puanın $(\mathrm{M}=3.69, \mathrm{SD}=.53)$ ise hem 7.sinıf öğrencilerinin ortalama puanlarından $(\mathrm{M}=3.58, \mathrm{SD}=.57)$ hem de 8.sınıf öğrencilerinden elde edilen ortalama puanlardan $(\mathrm{M}=3.59$, $\mathrm{SD}=.57)$ anlamlı şekilde farklılaştığı görülmektedir. Öğrenci uzlaşması alt boyutu için Dunnett C testi kullanılan Post-hoc kıyaslamalar, 5.sını öğrencilerinden elde edilen ortalama puanın ( $\mathrm{M}=3.68, \mathrm{SD}=.54)$ hem 7.sınıf öğrencilerinin ortalama puanlarından $(\mathrm{M}=3.58, \mathrm{SD}=.57)$ hem de 8.sınıf öğrencilerinden elde edilen ortalama puanlardan $(\mathrm{M}=3.59, \mathrm{SD}=.57)$ anlamlı şekilde farklılaştığını göstermektedir. Ayrıca paylaşımlı kontrol alt boyutu için Scheffe ve Tukey HSD testi kullanılan Post-hoc kıyaslamalar, 6.sınıf öğrencilerinden elde edilen ortalama puanın $(\mathrm{M}=3.69, \mathrm{SD}=.53)$ 7.sınıf öğrencileri için elde edilen ortalama puandan $(\mathrm{M}=3.58, \mathrm{SD}=.57)$ anlamlı bir biçimde farklı olduğunu işaret etmektedir. Diğer yandan kritik fikir alt boyutu için Dunnett $C$ testi kullanılan Post-hoc kıyaslamalar, 5.sınıf öğrencilerinden elde edilen ortalama puanın $(\mathrm{M}=3.68, \mathrm{SD}=.54)$, 7.sınıf öğrencileri için elde edilen ortalama puandan $(\mathrm{M}=3.58, \mathrm{SD}=.57)$ anlamlı bir biçimde farklı olduğunu ve buna ek olarak, 6.sınıf öğrencilerinden elde edilen ortalama puanın $(\mathrm{M}=3.69, \mathrm{SD}=.53)$ hem 7.sınıf öğrencilerinin ortalama puanlarından ( $\mathrm{M}=3.58, \mathrm{SD}=.57)$ hem de 8.sınıf öğrencilerinden elde edilen ortalama puanlardan $(\mathrm{M}=3.59, \mathrm{SD}=.57)$ anlamlı şekilde farklılaştı̆̆ını göstermektedir. Özetle, 5. ve 6.sınıf öğrencilerinin okullarındaki yapılandırmacı öğrenme ortamına yönelik algılarının 7. ve 8.sınıf öğrencilerine oranla daha yüksek düzeyde olduğu söylenebilir. Buna göre, ortaokul 5. ve 6.sınıf öğrencilerinin, 7. ve 8.sınıf öğrencilerine oranla daha yüksek düzeyde; okulda daha iyi öğrenmeleri için birbirleriyle daha çok etkileşimde bulunmaları gerektiğine $(\mathrm{F}=5.76, \mathrm{p}<.05, \eta=.08)$, kendi öğrenmeleri üzerinde kontrol sahibi olduklarına $(\mathrm{F}=4.20, \mathrm{p}<.05$, 
$\eta=.07)$ ve kendi öğrenmeleriyle ilgili düşüncelerini açıklama özgürlüğ̈ne sahip oldukları algısına ( $F=7.87$, $\mathrm{p}<.05, \eta=.09)$ sahip oldukları ortaya çıkmıştır. Tüm bu sonuçlar Tablo 4'te toplu halde sunulmuştur.

Tablo 4. Öğrenci algılarının sınıf düzeylerine göre farklılaşma durumuna ilişkin ANOVA sonucu

\begin{tabular}{|c|c|c|c|c|c|c|c|c|}
\hline Boyutlar & Sınıf Düzeyi & $\mathbf{M}$ & SD & $\mathbf{F}$ & $\mathrm{p}$ & $\begin{array}{c}\text { Levene's } \\
\text { Test }\end{array}$ & $\eta$ & $\begin{array}{c}\text { Scheffe; } \\
\text { Dunnett C; } \\
\text { Tukey HSD }\end{array}$ \\
\hline \multirow{4}{*}{$\begin{array}{l}\text { Ölçek Bütünü } \\
\text {-YÖOÖ- }\end{array}$} & 5. Sinif & 3.68 & .54 & \multirow{4}{*}{6.26} & \multirow{4}{*}{$\mathrm{p}<.05$} & \multirow{4}{*}{$\mathrm{p}>.05$} & \multirow{4}{*}{.08} & \multirow{4}{*}{$\begin{array}{l}\text { A-C* } \\
\text { B-C } \\
\text { B-D }\end{array}$} \\
\hline & 6. Sinif & 3.69 & .53 & & & & & \\
\hline & 7. Sinif & 3.58 & .57 & & & & & \\
\hline & 8. Sinif & 3.59 & .57 & & & & & \\
\hline \multirow{4}{*}{$\begin{array}{l}\text { Öğrenci } \\
\text { Uzlaşması }\end{array}$} & 5. Sinif & 3.59 & .78 & \multirow{4}{*}{5.76} & \multirow{4}{*}{$\mathrm{p}<.05$} & \multirow{4}{*}{$\mathrm{p}<.05$} & \multirow{4}{*}{.08} & \multirow{4}{*}{$\begin{array}{l}\text { A-C } \\
\text { A-D }\end{array}$} \\
\hline & 6. Sinif & 3.48 & .79 & & & & & \\
\hline & 7. Sinif & 3.40 & .80 & & & & & \\
\hline & 8. Sinif & 3.43 & .87 & & & & & \\
\hline \multirow{4}{*}{$\begin{array}{l}\text { Paylaşımlı } \\
\text { Kontrol }\end{array}$} & 5. Sinif & 3.33 & .92 & \multirow{4}{*}{4.20} & \multirow{4}{*}{$\mathrm{p}<.05$} & \multirow{4}{*}{$\mathrm{p}>.05$} & \multirow{4}{*}{.07} & \multirow{4}{*}{ B-C } \\
\hline & 6. Sinif & 3.36 & .92 & & & & & \\
\hline & 7. Sinif & 3.21 & .89 & & & & & \\
\hline & 8. Sinif & 3.23 & .89 & & & & & \\
\hline \multirow{4}{*}{ Kritik Fikir } & 5. Sinif & 3.99 & .68 & \multirow{4}{*}{7.87} & \multirow{4}{*}{$\mathrm{p}<.05$} & \multirow{4}{*}{$\mathrm{p}<.05$} & \multirow{4}{*}{.09} & \multirow{4}{*}{$\begin{array}{l}\text { A-C } \\
\text { B-C } \\
\text { B-D }\end{array}$} \\
\hline & 6. Sinif & 4.03 & .67 & & & & & \\
\hline & 7. Sinif & 3.85 & .77 & & & & & \\
\hline & 8. Sinif & 3.90 & .78 & & & & & \\
\hline
\end{tabular}

3.4. Öğgrencilerin yapılandırmacı öğrenme ortamına ilişkin algıları öğrenim görülen yıl açısından farklılaşmakta mıdır?

Öğrencilerinin okullarındaki yapılandırmacı öğrenme ortamına dair algılarını öğrenim gördükleri y1l açısından incelemek için tek faktörlü gruplar arası varyans analizi (ANOVA) yürütülmüştür. Öğrenciler öğrenim gördükleri yıllara göre dört gruba ayrilmıştır (A=2011; $B=2012 ; C=2013 ; D=2014)$. Analiz sonucunda öğrenci algılarının ölçeğin bütünü, kişisel uygunluk, öğrenci uzlaşması, paylaşımlı kontrol, kritik fikir ve belirsizlik alt boyutlarında anlamlı şekilde farklılaştığı belirlenmiştir. Buna göre, öğrencilerin yapılandırmacı öğrenme ortamına dair puan ortalamaları öğrenim gördükleri yıla göre istatistiksel açıdan anlamlı düzeyde farkl1lk göstermektedir $(\mathrm{F}=11.37, \mathrm{p}<.05, \eta=.11)$.

Ölçeğin bütünü için Scheffe, ve Tukey HSD testi kullanılan Post-hoc kıyaslamalar, 2011 yllinda öğrenim gören öğrencilerden elde edilen ortalama puanın $(\mathrm{M}=3.75, \mathrm{SD}=.55)$ sirasıly $2012(\mathrm{M}=3.58, \mathrm{SD}=.56), 2013$ $(\mathrm{M}=3.58, \mathrm{SD}=.53)$ ve $2014(\mathrm{M}=3.62, \mathrm{SD}=.57)$ y1llarında öğrenim gören öğrencilerden elde edilen ortalama puanlardan anlamlı şekilde farklılaştığına işaret etmektedir. Ayrıca kişisel uygunluk ve paylaşımlı kontrol alt boyutları için Scheffe, Dunnett C ve Tukey HSD testi kullanılan Post-hoc kiyaslamalar da, 2011 yllinda öğrenim gören öğrencilerden elde edilen ortalama puanın $(\mathrm{M}=3.75, \mathrm{SD}=.55)$ sirasiyla $2012(\mathrm{M}=3.58, \mathrm{SD}=.56)$, $2013(\mathrm{M}=3.58, \mathrm{SD}=.53)$ ve $2014(\mathrm{M}=3.62, \mathrm{SD}=.57)$ y1llarında öğrenim gören öğrencilerden elde edilen ortalama puanlardan anlamlı şekilde farklılaştığını ortaya koymuştur. Buna ek olarak, öğrenci uzlaşması ve kritik fikir alt boyutları için Scheffe ve Tukey HSD testi kullanılan Post-hoc kiyaslamalar, 2011 yılında öğrenim gören öğrencilerden elde edilen ortalama puanın $(\mathrm{M}=3.75, \mathrm{SD}=.55)$ sırasıyla $2012(\mathrm{M}=3.58, \mathrm{SD}=.56)$ ve 2013 $(\mathrm{M}=3.58, \mathrm{SD}=.53)$ yıllarında öğrenim gören öğrencilerden elde edilen ortalama puanlardan anlamlı şekilde farklılaştığını göstermektedir. Ölçeğin belirisizlik boyutu için ise Scheffe ve Tukey HSD testi kullanılan Posthoc kıyaslamalar, 2011 yllında öğrenim gören öğrencilerden elde edilen ortalama puanın $(\mathrm{M}=3.75, \mathrm{SD}=.55)$, $2013(\mathrm{M}=3.58, \mathrm{SD}=.53)$ ylllarında öğrenim gören öğrencilerden elde edilen ortalama puanlardan anlamlı şekilde farklılaştı̆̆ına da işaret etmektedir.

Buna göre, 2011 yılında öğrenim gören ortaokul öğrencilerinin okullarındaki yapılandırmacı öğrenme ortamına yönelik algilarının sırasıyla 2012, 2013 ve 2014 yıllarında öğrenim gören öğrencilere oranla daha yüksek düzeyde olduğu ifade edilebilir. Başka bir deyişle, 2011 yllında öğrenim gören ortaokul öğrencileri 2012, 2013 ve 2014 yıllarında öğrenim gören öğrencilere oranla daha yüksek düzeyde; okulda öğrendikleri bilgilerin okul içinde ve dışındaki deneyimleri ile ilişkili olduğuna $(\mathrm{F}=6.17, \mathrm{p}<.05, \eta=.08)$, okulda daha iyi öğrenmeleri için birbirleriyle daha çok etkileşimde bulunmaları gerektiğine $(F=5.25, \mathrm{p}<.05, \eta=.08)$, kendi öğrenmeleri 
üzerinde kontrole $(\mathrm{F}=5.02, \mathrm{p}<.05, \eta=.07)$ ve kendi öğrenmeleriyle ilgili düşüncelerini açılama özgürlüğüne sahip oldukları algısına $(\mathrm{F}=8.86, \mathrm{p}<.05, \eta=.10)$ sahiptirler. Ayrıca 2011 yllındaki öğrencilerin bilimin belirsiz doğasıyla ilgili algılarının $(\mathrm{F}=7.25, \mathrm{p}<.05, \eta=.09)$ da 2013 yılında öğrenim gören öğrencilere oranla daha yüksek düzeyde olduğu belirlenmiştir. Tüm bu sonuçlar Tablo 5 'te toplu halde sunulmuştur.

Tablo 5. Öğrenci algılarının sınıf düzeylerine göre farklılaşma durumuna ilişkin ANOVA sonucu

\begin{tabular}{|c|c|c|c|c|c|c|c|c|}
\hline Boyutlar & $\begin{array}{c}\text { Öğrenim } \\
\text { Y1lı }\end{array}$ & $\mathbf{M}$ & SD & F & $\mathrm{p}$ & $\begin{array}{c}\text { Levene's } \\
\text { Test }\end{array}$ & $\eta$ & $\begin{array}{c}\text { Scheffe; } \\
\text { Dunnett C; } \\
\text { Tukey HSD }\end{array}$ \\
\hline \multirow{4}{*}{$\begin{array}{l}\text { Ölçek Bütünü } \\
\text {-YÖOÖ- }\end{array}$} & 2011 & 3.75 & .55 & \multirow{4}{*}{11.37} & \multirow{4}{*}{$\mathrm{p}<.05$} & \multirow{4}{*}{$\mathrm{p}>.05$} & \multirow{4}{*}{.11} & \multirow{4}{*}{$\begin{array}{l}\text { A-B* } \\
\text { A-C } \\
\text { A-D }\end{array}$} \\
\hline & 2012 & 3.58 & .56 & & & & & \\
\hline & 2013 & 3.58 & .53 & & & & & \\
\hline & 2014 & 3.62 & .57 & & & & & \\
\hline \multirow{4}{*}{ Kişisel Uygunluk } & 2011 & 4.14 & .68 & \multirow{4}{*}{6.17} & \multirow{4}{*}{$\mathrm{p}<.05$} & \multirow{4}{*}{$\mathrm{p}<.05$} & \multirow{4}{*}{.08} & \multirow{4}{*}{$\begin{array}{l}A-B \\
A-C \\
A-D\end{array}$} \\
\hline & 2012 & 3.97 & .72 & & & & & \\
\hline & 2013 & 4.00 & .68 & & & & & \\
\hline & 2014 & 4.01 & .75 & & & & & \\
\hline \multirow{4}{*}{$\begin{array}{l}\text { Öğrenci } \\
\text { Uzlaşması }\end{array}$} & 2011 & 3.57 & .80 & \multirow{4}{*}{5.25} & \multirow{4}{*}{$\mathrm{p}<.05$} & \multirow{4}{*}{$\mathrm{p}>.05$} & \multirow{4}{*}{.08} & \multirow{4}{*}{$\begin{array}{l}\text { A-B } \\
\text { A-C }\end{array}$} \\
\hline & 2012 & 3.42 & .82 & & & & & \\
\hline & 2013 & 3.40 & .79 & & & & & \\
\hline & 2014 & 3.50 & .82 & & & & & \\
\hline \multirow{4}{*}{$\begin{array}{l}\text { Paylaşımlı } \\
\text { Kontrol }\end{array}$} & 2011 & 3.40 & .91 & \multirow{4}{*}{5.02} & \multirow{4}{*}{$\mathrm{p}<.05$} & \multirow{4}{*}{$\mathrm{p}>.05$} & & \multirow{4}{*}{$\begin{array}{l}\text { A-B } \\
\text { A-C } \\
\text { A-D }\end{array}$} \\
\hline & 2012 & 3.21 & .88 & & & & & \\
\hline & 2013 & 3.25 & .89 & & & & .01 & \\
\hline & 2014 & 3.28 & .93 & & & & & \\
\hline \multirow{4}{*}{ Kritik Fikir } & 2011 & 4.06 & .69 & \multirow{4}{*}{8.86} & \multirow{4}{*}{$\mathrm{p}<.05$} & \multirow{4}{*}{$\mathrm{p}>.05$} & \multirow{4}{*}{.10} & \multirow{4}{*}{$\begin{array}{l}\text { A-B } \\
\text { A-C }\end{array}$} \\
\hline & 2012 & 3.84 & .74 & & & & & \\
\hline & 2013 & 3.89 & .74 & & & & & \\
\hline & 2014 & 3.95 & .75 & & & & & \\
\hline \multirow{4}{*}{ Belirsizlik } & 2011 & 3.71 & .68 & \multirow{4}{*}{7.25} & \multirow{4}{*}{$\mathrm{p}<.05$} & & & \\
\hline & 2012 & 3.63 & .63 & & & $\mathrm{n}>05$ & 09 & $A_{C} C$ \\
\hline & 2013 & 3.54 & .62 & & & $p=.0 s$ & .07 & $11-C$ \\
\hline & 2014 & 3.62 & .63 & & & & & \\
\hline
\end{tabular}

$* \mathrm{~A}=2011 ; \mathrm{B}=2012 ; \mathrm{C}=2013 ; \mathrm{D}=2014$

\section{TARTIŞMA ve SONUÇ}

Bu çalışmada şu araştırma sorularına cevap aranmıştır: Öğrencilerin okullarındaki yapılandırmacı öğrenme ortamına yönelik algılarının ölçeğin bütünü ve alt boyutlarına göre farklılaşıp farklılaşmadığı; Öğrencilerin yapılandırmacı öğrenme ortamlarına ilişkin algılarının: Cinsiyet, sınıf düzeyi ve öğrenim görülen yıl değişkenleri açısından değişip değişmediği. Bu bağlamda öğrencilerin yapılandırmacı öğrenme ortamına ilişkin alg1 düzeylerinin örneklem grubunun tümü için $(M=3.64)$ "s1k s1k" düzeyinde ve yüksek bir oranda olduğu görülmüştür. Buna göre, öğrencilerin öğrenme ortamlarını oldukça yapılandırmacı olarak algıladıkları sonucuna ulaşılmışır. Ayrıca öğrenciler, en yüksek düzeyde öğrendikleri bilgilerin işlevsel olduğu görüşüne sahiplerken, en düşük düzeyde ise kendi öğrenmeleri üzerinde sahip oldukları kontrolden emin olamadıkları görüşündedirler. Bu önemli bir sonuçtur. Çünkü bu sonuç temel alındığında okullardaki öğrenme ortamlarının öğrencilerin üstbilişsel becerilerini geliştirme konusunda yeterli düzeyde olmayabileceği ifade edilebilir.

Öğrencilerin verdikleri yanıtların en çok kişisel uygunluk, en az paylaşımlı kontrol alt boyutlarında yer alan algılarda farklılaşma olduğu saptanmıştır. Diğger bir ifade ile öğrencilerin kendi öğrenmeleri üzerinde sahip oldukları kontrol ile ilgili algılarında farklılaşma gözlenirken, öğrendikleri bilgilerin işlevselliği hakkında benzer algılara sahip oldukları bulunmuştur.

Elde edilen bulgular 1şı̆̆ında; ilerlemecilik eğitim felsefesini programın temeline alan ve öğrencileri eğitim sisteminin merkezine alan ilköğretim programının sınıf ortamına ve öğrencilerin fen dersini öğrenirken tercih ettikleri öğrenme yaklaşımlarına yapıcı etkilerinin olduğu sonucuna ulaşılabilir Bu sonuç yakın zamanda yapılmış benzer araştırmaların sonuçlarıyla (Acat, Karadağ \& Kaplan, 2012; Belge Can, 2012; Çavuş \& Yılmaz, 2014; Özkal, Tekkaya \& Çakıroğlu, 2009) da örtüşmektedir

Ortaokul kademesinde eğitim-öğrenim gören öğrenciler sınıfta öğrendikleri bilgilerin sınıf dışında da işe yarar olduğuna, daha iyi öğrenmek için akranlarıyla işbirliği yapmanın faydalı olduğuna, kendi öğrenmelerinin 
sorumluluğunu alarak düşüncelerini özgürce ve demokratik yollarla açıklama özgürlüğüne sahip olmanın faydalı olduğuna ve öğrendikleri bilgilerden hareketle bilinmeyene doğru çıkarımlarda bulunmanın yararlı olduğuna inanmaktadırlar. Yine bu sonuçta konu hakkında yürütülmüş olan benzer araştırmaların sonuçlarıyla (Acat, Karadağ \& Kaplan, 2012; Belge Can, 2012; Çavuş \& Yılmaz, 2014; Özkal, Tekkaya \& Çakıroğlu, 2009) örtüşmektedir.

Öğrencilerin fen dersini öğrenirken konuya karşı ilgili olduğu, konunun derinlerinde yatan anlamı öğrenmeye çalıştığı, konuyu kendi deneyimleriyle anlamlandırdığı ve günlük hayatta kullandığı, var olan bilgileriyle yeni bilgiyi ilişkilendirdiği ve bu ilişkilere göre hipotezler kurup, test ettiği yani anlamlı öğrenme stratejilerini tercih ettiği çıkarımında bulunulabilir. Bu sonuç Belge Can'nın (2012) çalışmasında ulaştı̆̆ sonuçlarla örtüşmektedir.

Kız öğrencilerin yapılandırmacı öğrenme ortamına ilişkin alg1larının ölçeğin bütünü ve tüm alt boyutlarında erkek öğrencilerden daha yüksek olarak anlamlı bir şekilde farklılaştığı görülmüştür. Yani kız öğrenciler erkeklere oranla daha yüksek bir düzeyde; sınıfta öğrendikleri bilgilerin sınıf dışında da işe yarar olduğuna, daha iyi öğrenmek için akranlarıyla işbirliği yapmanın faydalı olduğuna, kendi öğrenmelerinin sorumluluğunu alarak düşüncelerini özgürce ve demokratik yollarla açıklama özgürlüğüne sahip olmanın faydalı olduğuna ve öğrendikleri bilgilerden hareketle bilinmeyene hakkında çıkarımlarda bulunmanın yararlı olduğu algısına sahiptirler. Bu sonuç konuya iliş̧kin diğer araştırmaların (Baş, 2012; Çavuş \& Yılmaz, 2014; Zorlu \& Zorlu, 2015) sonuçlarıyla örtüşmemektedir

Ortaokul 5. ve 6. sınıf öğrencilerinin yapılandırmacı öğrenme ortamına ilişkin algılarının ölçeğin bütünü ve tüm alt boyutlarında 7. ve 8. sınıf öğrencilerden daha yüksek olarak anlamlı bir şekilde farklılaştığı belirlenmiştir. Yani 5. ve 6. sınıf öğrencileri 7. ve 8. sınıf öğrencilerine oranla daha yüksek bir düzeyde; sınıfta öğrendikleri bilgilerin sınıf dışında da işe yarar olduğuna, daha iyi öğrenmek için akranlarıyla işbirliği yapmanın faydalı olduğuna, kendi öğrenmelerinin sorumluluğunu alarak düşüncelerini özgürce ve demokratik yollarla açıklama özgürlügüne sahip olmanın faydalı olduğuna ve öğrendikleri bilgilerden hareketle bilinmeyene doğru çıarımlarda bulunmanın yararlı olduğuna dair bir algiya sahiptirler. Bu sonuç, Zorlu ve Zorlu’nun (2015) bulgularıyla da örtüşmektedir. Ayrıca Zorlu ve Zorlu'nun (2015) araştırmasına göre; öğretmenler, 7. ve 8. sınıflarda Fen ve Teknoloji dersindeki konuların 5. ve 6. sınıflara göre daha uzun sürdüğünü ve öğretmenlere göre, 7. ve 8. sinıfta olan öğrencilerin, derslerin tamamen öğretmen tarafindan anlatılarak işlenilmesini istemekte olduklarını belirtmişlerdir.

Araştırmanın belki de dikkati çeken en önemli sonucu ise; 2011 yllında öğrencilerin yapılandırmacı öğrenme ortamına ilişkin alg1larının ölçeğin bütünü ve tüm alt boyutlarında 2012, 2013 ve 2014 yllındaki öğrencilerden daha yüksek olarak anlamlı şekilde farklılaşmış olmasıdır. Yani 2011 yılındaki 5, 6, 7 ve 8. sınıf öğrencilerinin 2012, 2013 ve 2014 yıllarındaki 5, 6, 7 ve 8.sınıf öğrencilere oranla daha yüksek bir düzeyde; sınıfta öğrendikleri bilgilerin sınıf dışında da işe yarar olduğuna, daha iyi öğrenmek için akranlarıyla işbirliği yapmanın faydalı olduğuna, kendi öğrenmelerinin sorumluluğunu alarak düşüncelerini özgürce ve demokratik yollarla açıklama özgürlüğune sahip olmanın faydalı olduğuna ve öğrendikleri bilgilerden hareketle bilinmeyene doğru çıkarımlarda bulunmanın yararlı olduğu algısına sahip oldukları ortaya çıkmıştır. Zorlu ve Zorlu'nun (2015) araştırmasına göre; öğretmeneler 4+4+4 eğitim sisteminde özellikle 8. sinıflarda son yıllarda sürekli olarak yapılan değişikliklerden dolayı ortaokul Fen ve Teknoloji dersinde öğrencilerin ve öğretmenlerin zorlandıklarını ifade etmektedirler. Bu konuya ilişkin olarak küçük bir kronoloji bilgisi: 4+4+4 sistemine geçiş 11 Mart 2012 (2012-2013 eğitim öğretim dönemi); ilköğretim ve ortaöğretim programı revizyonu 13 Şubat 2013; TEOG (2013-2014 eğitim öğretim dönemi) şeklindedir.

\section{1. Öneriler}

Araştırmacılara yönelik öneriler:

* İlgili alanda yapılacak çalışmaların karma araştırma dizaynı kullanarak gerçekleştirilmesi böylece daha detaylı bilgi elde edilmesi önerilebilir.

* Ortaokul kademesinde öğrenim gören öğrencilerinin kendi öğrenmeleri üzerinde daha çok söz sahibi olabilmesi, hem süreçte hem de değerlendirme aşamalarında daha katıllımcı olabilmesi ve işbirliği 
sağlayacak sosyal davranışları daha çok içselleştirebilmesi için daha detaylı araştırma yapılması ve çözüm yolları üretilmesi önerilebilir.

* 4+4+4 eğitim sistemi üzerinde izleme ve değerlendirme yoluyla geri besleme çalışmalarının paydaşların (TUBİTAK ve MEB gibi) katılımıyla projelendirilmesi önerilebilir.

Politika yapıcılar ve yürütücülere yönelik öneriler:

* Yapılandırmacı sınıf ortamları oluşturmaya dayalı ekinliklerin üretimi ve ortam tasarımına yönelik yüzeysel değil daha kalıcı izli değişikliklere dikkat çekecek seminer, kurs vb. bilgilendirme faaliyetlerine okullarda daha fazla ağırlık verilebilir.

* Okullarda yapılandırmacı öğrenme ortamlarının oluşturulmasına yönelik daha çok proje gerçekleştirilmesi için öğretmenler ve araştırmacılar bu konuda teşvik edilip desteklenebilirler.

\section{KAYNAKÇA}

Acat, M. B., Karadağ, E. \& Kaplan, M. (2012). Kırsal bölgelerde fen ve teknoloji dersi öğrenme ortamlar1: Yapılandırmacı öğrenme açısından bir değerlendirme çalışması. Dicle Üniversitesi Ziya Gökalp Eğitim Fakïltesi Dergisi, 18 (2012) 106-119.

Arısoy, N. (2007). 8. sinf ögrencilerinin fen derslerindeki ögrenme ortamlarna yönelik algzlar ile güdüsel inanç ve tutumlar arasindaki ilişkinin incelenmesi (Yayınlanmamış doktora tezi). Orta Doğu Teknik Üniversitesi, Ankara.

Arkün, S. \& Aşkar, P. (2010). Yapılandırmacı öğrenme ortamlarını değerlendirme ölçeğinin geliştirilmesi. Hacettepe Üniversitesi Ë̆itim Fakültesi Dergisi (H. U. Journal of Education), 39, 32-43.

Ayaz, M. F. \& Şekerci, H. (2015). Yapılandırmacı öğrenme yaklaşımının akademik başarıya ve tutuma etkisi: Bir meta-analiz çalışması. Hasan Ali Yücel Eğitim Fakültesi Dergisi, 12(24), 27-44.

Aygören, F. (2009). Yapılandrrmacı ögrenme ortamlarmun simf ögretmenlerinin ve okul yöneticilerinin görüslerine göre

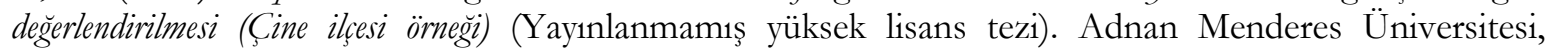
Aydin.

Aygören, F. \& Saracaloğlu, A. S. (2015). Yapılandırmacı öğrenme ortamlarının okul yöneticilerinin görüşlerine göre incelenmesi. Uluslararası Ë̈itim Bilimleri Dergisi, 2(4), 562-581.

Baki, A. \& Bell, A. (1997). Ortaögretim matematik ögretimi. Ankara: YÖK.

Baş, G. (2012). İlköğretim öğrencilerinin yapılandırmacı öğrenme ortamına ilişkin algılarının farklı değişkenler açısından değerlendirilmesi. Ë̆itim ve Öğretim Araştrmaları Dergisi, 1(4), 203-215.

Belge Can, H. (2012). İlköğretim öğrencilerinin öğrenme ortamları ile ilgili algılarının değerlendirilmesi. X. Ulusal Fen Bilimleri ve Matematik. Eğitimi Kongresi, Tam Metin Bildiri Kitapçı̆̆ı, 27-30 Haziran 2012, Niğde, TÜRKIYE.

Çavuş, R. \& Yılmaz, M. M. (2014). Ortaokul öğrencilerinin fen ve teknoloji dersindeki yapılandırmacı öğrenme ortamına ilișkin görüşlerinin farklı değișkenlere göre incelenmesi. Fen Eğitimi ve Araștırmalar Derneği Fen Bilimleri Ögretimi Dergisi, 2(2), 110-128.

Entwistle, N. J. (1991). Approaches to learning and perceptions of the learning environment. Higher education, 22(3), 201-204.

Entwistle, N., \& Tait, H. (1990). Approaches to learning, evaluations of teaching, and preferences for contrasting academic environments. Higher education, 19(2), 169-194.

Honebein, P. C., (1998) Seven goals for the design of constructivist learning environment, Wilson, B.G. (Ed.). Constructivist learning environments. New Jersey: Educational Technology Publications, USA.

Johnson, B., \& McClure, R. (2004). Validity and reliability of a shortened, revised version of the constructivist learning environment survey (CLES). Learning Environments Research, 7, 65-80.

Jonassen, D. H., Peck, K. L., \& Wilson, B. G. (1999). Learning with technology: A constructive perspective. New York: Prentice-Hall Inc, USA.

Küçüközer, H., Kırtak Ad, V. N., Ayverdi, L. \& Eğdir, S. (2012). Yapılandırmacı öğrenme ortamları ölçeğinin Türkçe'ye uyarlanması. İlköğretim Online, 11(3), 671-688.

Meral, E. \& Şimşek, U. (2014). Sosyal bilgiler dersinde işbirlikli öğrenme yöntemlerinin 6.sınıf öğrencilerinin akademik başarılarına etkisi. Journal of Computer and Education Research, 2(4), 134-151.

Metin, M. (2014). Kuramdan Uygulamaya Eğitimde Bilimsel Araştırma Yöntemleri. Ankara: Pegem Akademi Yayıncllik.

Ocak, G. \& Tavlı, M. (2010). Yapılandırmacı öğrenme ortamları. Eğitime Bakııs, 6(16), 51-55.

Özden, Y. (2003). Öğrenme ve ögretme. Ankara: Pegem A Yayıncilık.

Özkal, K., Tekkaya, C. \& Çakıroğlu, J. (2009). Sekizinci sınıf öğrencilerinin yapılandırıcı fen öğrenme ortamı hakkındaki algilarının incelenmesi. Eğitim ve Bilim, 34(153), 38-46. 
Polat, M. \& Köse, Y. (2013). Okullarda bir performans değerlendirme aracı olarak e-portfolyo kullanımına yönelik ilköğretim öğretmenlerinin görüşleri. Journal of Computer and Education Research, 1(1), 59-82.

Taylor, P. C., \& Fraser, B. J. (1991). Development of an instrument for assessing constructivist learning environments. Paper presented at the Annual Meeting of the National Association for Research in Science Teaching (NARST), The Abbey, Fontane, Wisconsin.

Trigwell, K., \& Prosser, M. (1991). Improving the quality of student learning: the influence of learning context and student approaches to learning on learning outcomes. Higher education, 22(3), 251-266.

Uysal, E. (2010). Bir modelleme çalșmasi: İlköğretim öğrencilerinin epistemolojik inanclar, öğrenme ortamlar ile ilgili alguları, ögrenme yaklaşımlar ve fen başarılar arasındaki ilişkiler (Yayınlanmamış doktora tezi). Orta Doğu Teknik Üniversitesi, Ankara.

Yılmaz-Tüzün, Ö., Çakıroğlu, J., \& Boone. W. J. (2006). Turkish high school student's perceptions of constructivist learning environment in chemistry classrooms and their attitudes toward chemistry. Paper presented at the National Association for Research in Science Teaching (NARST), April 3-6, San Francisco, USA.

Zorlu, Y. \& Zorlu, F. (2015). Fen ve teknoloji dersinde öğrenme ortamına yönelik öğrencilerin düzeyleri ve öğretmenlerin görüşleri. Route Educational and Social Science Journal, 2(1), 103-114.

\section{Citation Information}

Erdoğan, İ. \& Polat, M. (2017). Okullarımız Yapılandırmacı Öğrenme Ortamlarına Ne Kadar Sahip? Ortaokul Öğrencilerinin Alg1ları Üzerine Boylamsal Bir Bakış. Dicle Üniversitesi Ziya Gökalp Eğitim Fakültesi Dergisi, 30, 608-618. 